\title{
Informed Parents- Safe Environment for Children*
}

\section{Bilgilli Ebeveynler- Çocuklar için Güvenli Ortam}

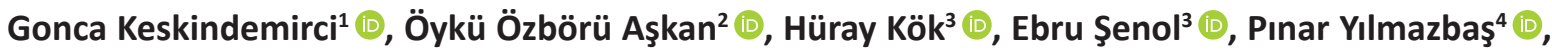 Yeşfa Şebnem Özbay ${ }^{3}$, Gülbin Gökçay ${ }^{\text {ID }}$}

\author{
${ }^{1}$ Istanbul University, İstanbul Medical Faculty, Department of Pediatrics Division of Social Pediatrics, İstanbul, Turkey \\ ${ }^{2}$ istanbul University, Institute of Child Health Department of Social Pediatrics, İstanbul, Turkey \\ ${ }^{3}$ istanbul University, Institute of Health Sciences and Institute of Child Health Social Pediatrics PhD Program, İstanbul, Turkey \\ ${ }^{4}$ University of Health Science, Prof. Dr. Cemil Taşçıoğlu City Hospital, Well Child Outpatient Clinic, İstanbul, Turkey
}

ORCID ID: G.K. 0000-0003-1797-2802; Ö.Ö.A. 0000-0002-4139-5497; H.K. 0000-0001-7519-0185; E.Ş. 0000-0001-9015-1846; P.Y. 0000-0002-1283-1712; Y.Ş.Ö. 0000-0003-3473-0135; G.G. 0000-0003-1042-0407

Citation/Att: Keskindemirci G, Ozboru Askan O, Kok H, Senol E, Yilmazbas P, Ozbay YS, Gokcay G. Informed parents- safe environment for children. Çocuk Dergisi - Journal of Child 2021;21(3):260-265. https://doi.org/10.26650/jchild.2021.989506

ABSTRACT

Objective: Childhood injury is a significant public health problem. This study aimed to evaluate the awareness of families about accident/injury risks both indoors and outdoors and provide counselling within the scope of parent education by using tools related to environmental safety. Material and Methods: This study was a two-centered, prospective study conducted with the participation of parents with children under the age of five. Initially, a preliminary assessment was made using a questionnaire. Then, face-to-face training was provided using an infographic brochure from the "Basic Information for Families for Child Health and Safety in the First 5 Years" booklet created by the Child Health Association (https:// cocuksagligidernegi.org/). Parents were given a "Safety Checklist" so they could assess child safety at home. In the third and sixth months, families were called and asked questions again about their attitudes and behaviors towards preventing accidents/injuries.

Results: A total of 157 parents were included in the study. It was determined that the rates of safe behavior in-car safety, sleep safety, toy safety, kitchen and bathroom safety, and indoor arrangements increased statistically.

Conclusion: Family counseling and education can lead to behavioral change to create a safe environment for children and prevent accidents/ injuries. Multifaceted initiatives are more likely to successfully reduce injuries at home and increase the effectiveness of education with the use of infographic materials, continuity of education, preparing checklists to be applied at home and sharing them with families.

Keywords: Accident/Injury, child safety, education öz

Amaç: Çocukluk çağında yaralanmalar önemli bir halk sağlığı sorunudur. Çalışmamızda, ailelerin hem iç, hem de dış mekanlarda kaza/yaralanma riskleri konusundaki farkındalıklarını değerlendirmeyi ve çevre güvenliği ile ilgili araçlar kullanarak anne baba eğitimi kapsamında danışmanlık vermeyi amaçladık.

Gereç ve Yöntemler: Çalışmamız, beş yaşından küçük çocuğu olan anne babaların katılımı ile yürütülen iki merkezli, ileriye dönük bir çalışmadır. Başlangıçta, anket kullanılarak ön değerlendirme yapıldı. Çocuk Sağlığı Derneği (https://cocuksagligidernegi.org/) tarafından hazırlanan "ilk 5 Yaşta Çocuk Sağlığı ve Güvenliği İçin Ailelere Temel Bilgiler" kitapçı̆̆ından hazırlanan bir infografik broşür kullanılarak yüz yüze eğitim verildi. Anne babalara evlerinde çocuk güvenliğini değerlendirebilmeleri için bir "Güvenlik Kontrol Listesi" verildi. Üçüncü ve altıncı aylarda aileler aranarak kazaları/yaralanmaları önlemeye yönelik tutum ve davranışlarını değerlendiren sorular tekrar soruldu.

Bulgular: Çalışmaya toplam 157 anne baba alındı. Eğitimden sonra; araç içi güvenlik, uykuda güvenlik, oyun ve oyuncak güvenliği, mutfak ve banyo güvenliği ve iç mekan düzenlemelerine ilişkin güvenli davranış oranlarının istatistiksel olarak arttığı saptandı.

Sonuç: Aile danışmanlığı ve eğitimi, çocuklar için güvenli bir ortam yaratmak ve kazaları/yaralanmaları önlemek için davranış değişikliğine yol açabilmektedir. İnfografik materyallerin kullanılması, eğitimin sürekliliğinin sağlanması, evde uygulanacak kontrol listelerinin hazırlanması ve ailelerle paylaşıması eğitimin etkinliğini artıracağından çok yönlü girişimlerin evdeki yaralanmaları başarılı bir şekilde azaltması daha olasıdır.

*This study was presented as an oral presentation at the "2nd International Eurasian Congress of Social Pediatrics and $6^{\text {th }}$ National Congress of Social Pediatrics".

Corresponding Author/Sorumlu Yazar: Gonca Keskindemirci E-mail: keskindemirci@hotmail.com

Submitted/Başvuru: 03.09.2021 • Revision Requested/Revizyon Talebi: 30.09.2021 • Last Revision Received/Son Revizyon: $02.11 .2021 \bullet$

Accepted/Kabul: 03.11.2021 


\section{INTRODUCTION}

Child injury is a significant public health problem. As a result of unintentional injuries, more than 2000 children die every day, and millions of children suffer non-fatal injuries that could cause long-term hospitalization and rehabilitation (1). Children are more susceptible to accidents than any other age group because of their specific behavioral, physiological, and developmental characteristics (2). Most injuries among young children occur in the home environment, and are associated with the family's socio-economic factors, the physical home environment, and the child's developmental characteristics (3). As children are curious by nature, learn with experience, cannot realize cause-effect relationships, spend most of their time on the floor, and their motor coordination development is not fully accomplished, the risk of injuries increases (2-4). It is known that falls, burns, foreign body aspirations, and intoxications are the most common injuries in the pre-school age group, and these injuries mostly take place in the living room, kitchen, and bathroom $(5,6)$. Turkish data shows indoor injuries as the second most common cause of death following traffic accidents in children ages one to seventeen. The most common indoor injuries specified are falls, drowning, burns, and intoxications $(4,7)$.

The WHO report announces that $90 \%$ of injuries are preventable with relatively simple yet proven measures such as car seats, bicycle helmets, fencing swimming pools, child-resistant containers, window bars, and hot water temperature legislation (2). Therefore, primary prevention practices should be a priority in preventing injuries and providing children's wellbeing. Previous studies showed that questioning the injury risks and safety measures in well child follow-ups, family education, and home visits were effective methods in prevention of childhood unintentional injuries (8-11). Prevention studies that use infographics in parental education are limited in the literature.

In this study, the primary aim was to evaluate the parents' awareness about injury risks both indoors and outdoors and to provide counseling within parental education using infographics about environmental safety. The secondary aim was to compare parents' knowledge before and after education and its reflection on environmental safety practices.

\section{MATERIAL AND METHODS}

Our study was a two-centered, prospective, interventional study conducted in Istanbul University, Istanbul Faculty of Medicine, Department of Pediatrics, Division of Social Pediatrics Well-Child Outpatient Clinic and Health Sciences University Okmeydanı Training and Research Hospital, in the Well-Child Outpatient Clinic in Istanbul, Turkey between February 2020 and March 2020. Parents with children less than five years of age and who consented were included in the study. Growth and developmental evaluation, vaccination, and authoritative parenting consultancy were given to parents of all applied children.

Data on social-demographic characteristics, parental age, family income level (below or above the minimum wage) educational year, working status, number of households, and the age of the child were recorded at baseline. Then, a pre-evaluation questionnaire consisting of eight questions was completed in a face-to-face interview to evaluate the knowledge on practices of a safe environment (Table 1). After the preevaluation questionnaire, child health professionals working in social pediatrics gave face-to-face training using the Informed Parents-Safe Society brochure. The booklet "Basic Information

Table 1: The comparison of assessments before the training and at the third month after the training

\begin{tabular}{|c|c|c|c|}
\hline Injury prevention ( $\left.n^{\natural)}\right)$ & Age & 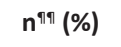 & $\mathbf{p}$ \\
\hline \multirow[t]{2}{*}{ Car safety $(n=86)$} & 0. month & $45(52)$ & $0.000^{*}$ \\
\hline & $3^{\text {rd }}$ month & $57(66)$ & \\
\hline \multirow[t]{2}{*}{ Sleep safety (Sleeping position) ( $n=147$ ) } & 0. month & $58(40)$ & $0.000^{* *}$ \\
\hline & $3^{\text {rd }}$ month & $97(66)$ & \\
\hline \multirow[t]{2}{*}{ Sleep safety (Pillow use) ( $n=150)$} & 0. month & $117(78)$ & $0.000^{*}$ \\
\hline & $3^{\text {rd }}$ month & $143(95)$ & \\
\hline \multirow[t]{2}{*}{ Right knowledge of a small object definition (139) } & 0. month & $2(1)$ & $0.029 *$ \\
\hline & $3^{\text {rd }}$ month & $24(17)$ & \\
\hline \multirow[t]{2}{*}{ Balloon safety $(n=151)$} & 0. month & $98(65)$ & 0.062 \\
\hline & $3^{\text {rd }}$ month & $128(85)$ & \\
\hline \multirow[t]{2}{*}{ Poison safety (safe storage of household cleaning products, etc.) (n=86) } & 0. month & $19(22)$ & $0.000^{*}$ \\
\hline & $3^{\text {rd }}$ month & $24(28)$ & \\
\hline \multirow[t]{2}{*}{ Safe use of furniture and TV $(n=150)$} & 0. month & $41(27)$ & $0.000^{* *}$ \\
\hline & $3^{\text {rd }}$ month & $64(43)$ & \\
\hline
\end{tabular}

*Fischer-Exact Test; **Chi-square Test.

"number of parents who responded to this "number of parents who answered correctly 
for Families for Child Health and Safety in the First 5 Years" prepared by the Child Health Association was used (https:// cocuksagligidernegi.org/) was used as a model for the brochure used in the study. The brochure of infographics consisted of information on practices of car safety, sleep safety (especially sleep position and pillow use), safe toys for children (especially knowledge of a small object and balloon safety), providing a safe area in the kitchen and bathroom (especially safe storage of household cleaning products), and the living room with furniture and television (TV). Four Social Pediatrists trained the families separately and the training took 15-20 minutes.

After the training, a "Security Checklist" which was adopted from the documents by Baysal et al. (12) was given to the family to evaluate home safety. The checklist consisted of forty-three items including car safety (6 items), safety in living room, sleep safety, safe toys (18 items), safety in the kitchen (11 items), safety in the bathroom ( 6 items) and safety outdoors ( 2 items). In the third and sixth months, families were called and questions evaluating the attitudes and behaviors about preventing injuries were asked again. We evaluated whether the unsafe practices persisted or not and made repetition about the inappropriate ongoing practices.

The Istanbul University, Istanbul Medical Faculty Ethical Committee approved the study (Protocol No: 2019/1290) and all participants gave written informed consent.

\section{RESULTS}

A total of 157 parents who agreed to participate in the study filled out a pre-evaluation form and were informed using a brochure. Mothers made up $94.3 \%$ of the participants and median (IQR) age of the participants was 33 (29-37) years.
Mean education time of the participants was $12( \pm 3.9)$ years. Median (IQR) age of the children was 12 (5-30) months and $46.5 \%$ of children were singleton.

A total correct answer score given in the pre-training questionnaire was correlated with the participants' education year $(p=0.005, r=0.221)$. However, no correlation was found between participants' education year and the score difference between pre-training questionnaire and the questionnaire 3 and 6 months after training.

After training, there was an increase in car safety behaviors, the correct safe sleep position, knowing the age limit for pillow use, the definition of small objects/toys, paying attention for age about playing with balloons, safe storage of cleaning materials in the kitchen and bathroom, and safe use of furniture and TV in the living room ( $n=151$ [3 months], $n=135$ [ 6 months]). These differences were statistically significant. Education levels were not statistically significant among parents. The comparisons of pre-training evaluation and evaluations at 3 and 6 months after the training are given in Table 1-3.

\section{DISCUSSION}

In the present study, parents' awareness about injury risks both indoors and outdoors was evaluated by a pre-evaluation questionnaire and questionnaire after training using infographics about environmental safety. Their awareness was evaluated at the third and sixth month after training. After training, correct car safety behaviors, safe sleeping positions, knowing the age limit for pillow use, the definition of small objects/toys, paying attention for age about playing with balloons, safe storage of cleaning materials in the kitchen and bathroom, and safe use of furniture and TV were

Table 2: The comparison of assessments before the training and at the sixth month after the training

\begin{tabular}{|c|c|c|c|}
\hline Injury prevention ( $n^{\text {?) }}$ & Age & $\mathrm{n}^{\text {ๆศा }}(\%)$ & $\mathbf{p}$ \\
\hline \multirow[t]{2}{*}{ Car safety $(n=77)$} & 0. month & $38(49)$ & $0.000^{*}$ \\
\hline & $6^{\text {th }}$ month & $59(77)$ & \\
\hline \multirow[t]{2}{*}{ Sleep safety (Sleep position) ( $n=132)$} & 0. month & $51(39)$ & $0.007^{*}$ \\
\hline & $6^{\text {th }}$ month & $106(80)$ & \\
\hline & $6^{\text {th }}$ month & $133(99)$ & \\
\hline \multirow[t]{2}{*}{ Right knowledge of a small object definition $(n=134)$} & 0. month & $2(4)$ & $0.074^{*}$ \\
\hline & $6^{\text {th }}$ month & $52(39)$ & \\
\hline \multirow[t]{2}{*}{ Balloon safety $(n=135)$} & 0. month & $91(67)$ & $0.005^{*}$ \\
\hline & $6^{\text {th }}$ month & $128(95)$ & \\
\hline \multirow[t]{2}{*}{ Poison safety (safe storage of household cleaning products) $(n=72)$} & 0. month & $18(25)$ & $0.000 * *$ \\
\hline & $6^{\text {th }}$ month & $19(26)$ & \\
\hline \multirow[t]{2}{*}{ Safe use of furniture and TV $(n=134)$} & 0. month & $34(25)$ & $0.000^{*}$ \\
\hline & $6^{\text {th }}$ month & $58(43)$ & \\
\hline
\end{tabular}

*Fischer-Exact test ${ }^{*}$ chi-square test

"number of parents who responded to this "number of parents who answered correctly 
Table 3: The comparison of assessments at the third month and at the sixth month after the training

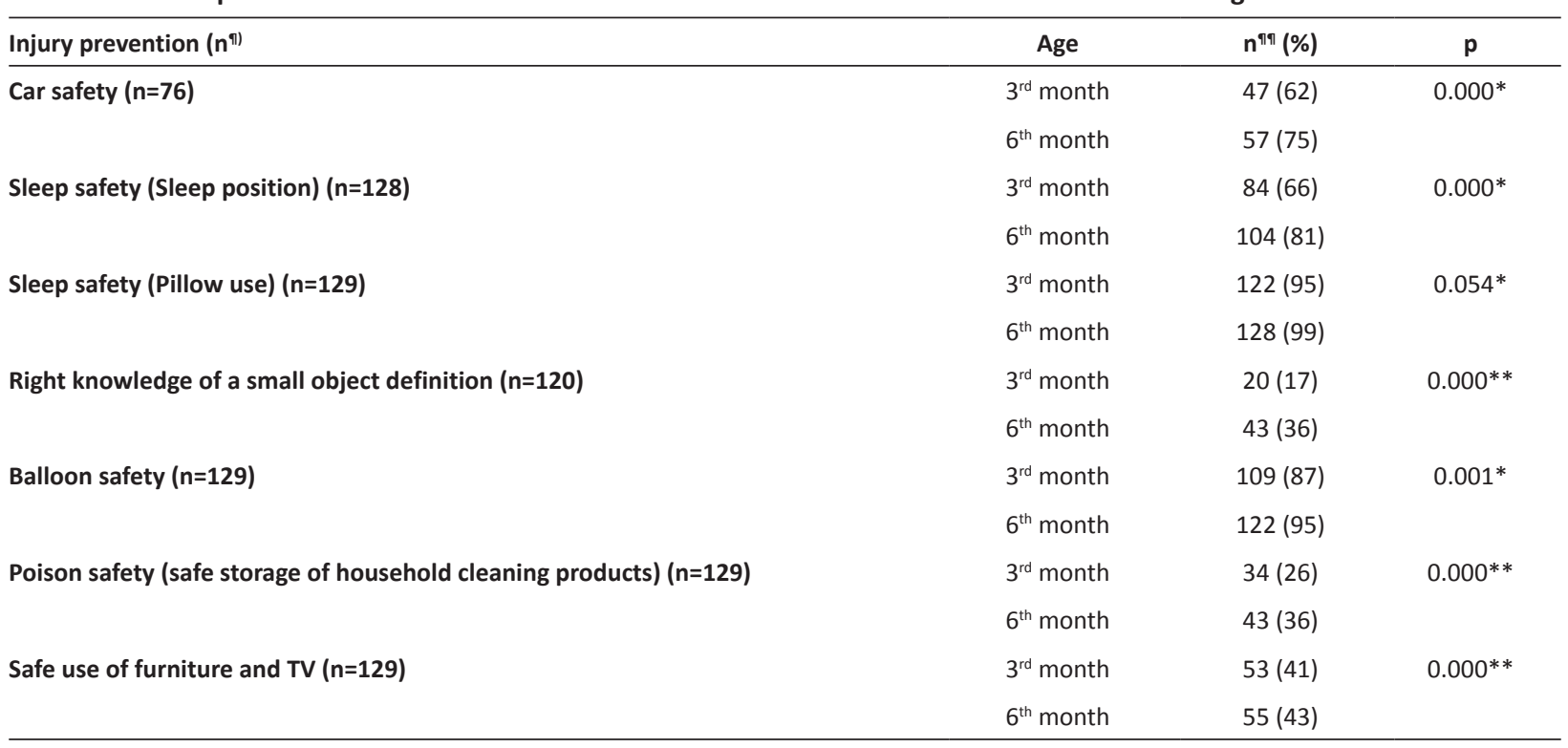

*Fischer-Exact test ${ }^{*}$ chi-square test

"number of parents who responded to this "number of parents who answered correctly

increased statistically. In addition, this study showed that family counselling and training are an essential part of well-child visits.

The most effective way to protect children from motor vehicle traffic accidents is to use a child car seat system. The National Highway Traffic Safety Administration "NHTSA" reported that when these systems are used correctly in the USA, infant deaths under one year will be reduced by $71 \%$ and child deaths aged $1-4$ years by $54 \%$ (13). According to 2013 data from the Health Statistics Yearbook of the Ministry of Health of the Republic of Turkey, the rate of travelling in the back seat of their private car and wearing a seat belt was $17.3 \%$ in $0-5$-year-olds (14). In the study of Andijani, the parents' rate of use of car seats was $30 \%$ and was significantly associated with education level and family income (15). Our study determined that the use of child car seats was low before training, but the use of it increased significantly after training with infographics. Family education plays a crucial role in child health follow-up, and our study shows the positive results of education.

The American Academy of Pediatrics reports that the most appropriate sleeping position to prevent Sudden Infant Death Syndrome is the supine position (lying on the back). Lying on the back does not pose a risk in terms of suffocation or aspiration (16-18). In our study, the number of parents who knew the correct sleeping position increased significantly after training. Therefore, it is vital that family counselling be started in the prenatal period, not postnatally, or as early as possible to reduce sudden infant death rates significantly.

Pillows are not recommended for infants under one year of age due to the risk of suffocation. In our study, while the use of pillows decreased significantly in the $3^{\text {rd }}$ month after the training, no significant decrease was found in the use of a pillow in the following months. The parents do not know that using a pillow may pose a risk in terms of baby safety. It is recommended for the baby to sleep on a hard, flat sleeping surface to reduce the risk of suffocation (19).

Children tend to put the items in their mouths as a part of their behavioral and motor development. In the study conducted by Öz et al. (5) which aimed to develop an injury control list and evaluate the risk of injury in 570 children aged $0-5$ years, $6.9 \%$ of the children suffered from foreign body aspiration (5). In a study conducted in the USA, it was reported that the annual foreign body aspiration rate per 10,000 children increased from 9.5 in 1995 to 18 in 2015, which increased by 91.5\% (20). The researchers in this study observed that the families did not have clear information about the dimensions of objects that would pose a risk for foreign body aspiration. Therefore, a toilet paper roll is recommended as a measuring tool (21). In this study, training was given on its use as a measuring tool and feedback was received after the education that parents used this information in their daily lives to identify small-piece toys for their children and thus take precautions for foreign body aspiration.

The U.S. Consumer Product Safety Commission (CPSC) has reported balloons as the leading cause of childhood deaths from suffocation among all children's products. In addition, there is a risk of suffocation while trying to inflate the balloon, or the pieces of a burst balloon cause a risk of suffocation (22). The awareness and knowledge of families increased after the training on playing with balloons in the study.

In a study conducted by Kurt et al., the number of household injuries experienced by children in a year were examined, and it was determined that $67.3 \%$ of children had a home accident 
once, $23.5 \%$ had two accidents, and $9.2 \%$ had three or more accidents in their home environment. It has been reported that home accidents occur mainly in the living room, kitchen, and bathroom (23). The study of Kondolot et al., which evaluated the poisoning cases admitted to the pediatric emergency service, found that caustic/corrosive substance intake was the highest cause of poisoning admission in children aged eight months to five years. (24). Güloğlu et al. retrospectively analyzed the forty-two children admitted to the emergency room because of television-related injuries. Five children lost their lives, and the most frequent deaths were between 1-3 years old (25). In this study, an infographic brochure was used to educate parents about the precautions that must be taken in the kitchen, bathroom, and living room. After training, the researchers learned that arrangements improving home conditions were made. The study found that giving prevention checklists to reinforce parent training and education was effective.

Studies assessing the multifaceted interventions were found effective to prevent injuries in the literature (8-10). Our study was compatible with the literature as a multifaceted intervention using infographic training and a home checklist.

As a limitation, our study coincided with the COVID-19 pandemic period; the number of participants was less than expected, and all of the interviews were done by telephone due to the pandemic in the $3^{\text {rd }}$ and $6^{\text {th }}$ months.

In conclusion, family counselling and training are effective for those who take care of children to create a safe environment for minimizing injuries. In addition, multifaceted interventions are more likely to successfully reduce injuries in the home as using infographics, ensuring the continuity of the training, preparing the checklists to be applied at home and sharing them with the families will increase the effectiveness of the training.

This study was presented as an oral presentation in $2^{\text {nd }}$ International Eurasian Congress of Social Pediatrics and $6^{\text {th }}$ National Congress of Social Pediatrics.

Teşekkür: Katkılarından dolayı Gökçe Keskindemirci ve Mete Yılmazbaş’a teşekkür ederiz.

Etik Komite Onayı: İstanbul Üniversitesi İstanbul Tıp Fakültesi Etik Kurulu'ndan etik komite onayı alınmıştr. (Protokol No: 2019/1290)

Bilgilendirilmiş Onam: Katılımcılardan bilgilendirilmiş onam alınmıştır.

Hakem Değerlendirmesi: Dış bağımsız.

Yazar Katkıları: Çalışma Konsepti/Tasarım- G.K., H.K., E.Ş., P.Y., Y.Ş.Ö., G.G.; Veri Toplama- G.K., H.K., E.Ş., P.Y., Y.Ş.Ö., G.G.; Veri Analizi/ Yorumlama- G.K., Ö.Ö.A., G.G.; Yazı Taslağı- G.K., Ö.Ö.A., G.G., H.K., E.Ş., Y.Ş.Ö.; İ̧̧eriğin Eleştirel İncelemesi- G.K., G.G., Ö.Ö.A.; Son Onay ve Sorumluluk- G.K., G.G., H.K., E.Ş., P.Y., Y.Ş.Ö., Ö.Ö.A.

Çıkar Çatışması: Yazarlar çıkar çatışması beyan etmemişlerdir.

Finansal Destek: Bu proje Çocuk Sağlığı Derneği tarafindan desteklenmiştir.
Acknowledgement: We would like to thank Gökçe Keskindemirci and Mete Yılmazbaş for their contributions.

Ethics Committee Approval: Ethics committee approval was obtained from the Ethics Committee of Istanbul University, Istanbul Faculty of Medicine. (Protocol No: 2019/1290).

Informed Consent: Written consent was obtained from the participants.

Peer Review: Externally peer-reviewed.

Author Contributions: Conception/Design of Study- G.K., H.K., E.Ş., P.Y., Y.Ş.Ö., G.G.; Data Acquisition- G.K., H.K., E.Ş., P.Y., Y.Ş.Ö., G.G.; Data Analysis/Interpretation- G.K., Ö.Ö.A., G.G.; Drafting Manuscript- G.K., Ö.Ö.A., G.G., H.K., E.Ş., Y.Ş.Ö.; Critical Revision of Manuscript- G.K., G.G., Ö.Ö.A.; Final Approval and Accountability- G.K., G.G., H.K., E.Ş., P.Y., Y.Ş.Ö., Ö.Ö.A.

Conflict of Interest: Authors declared no conflict of interest.

Financial Disclosure: This project was supported by the Child Health Association.

\section{REFERENCES}

1. Peden AE, Franklin RC. Child Injury Prevention: It Is Time to Address the Determinants of Health. Children (Basel) 2021;46(8): 1-3.

2. Peden $M$, Oyegbite $K$, Ozanne-Smith J, et al., editors. World report on child injury prevention. World Health Organization; 2008.

3. Munro S, Van Niekerk A, Seedat M. Childhood unintentional injuries: the perceived impact of the environment, lack of supervision and child characteristics. Child Care Health Dev 2006;32(3):269-79.

4. T.C. Sağlık Bakanlığı Halk Sağ lığı Genel Müdürlüğü Çocuk ve Ergen Sağlığı Dairesi Başkanlığı. Çocuk Güvenliğinin Sağlanması Programı [Internet]. 2017 [cited 2021 Feb 3]. Available from: https://hsgm. saglik.gov.tr/tr/cocukergen-sgp1/saglıgın-gelisitirlmesi/çocukgüvenliğinin-sağlanması-programı.html. Last available time: 1 September 2021

5. Öz ŞS, Baysal SU, Gökçay G. Determination of injury risks in 0 to 5 years of age group children by a safety checklist. Turkiye Klinikleri J Pediatr 2017;26(2):50-9.

6. İnce T, Yalçın SS, Yurdakök K. Çocukluk çağında ciddi kaza sıklığı ve risk faktörleri. Çocuk Sağlığı ve Hast Derg 2014;57(3):173-82.

7. Hacettepe Üniversitesi Nüfus Etütleri Enstitüsü. 2018 Türkiye Nüfus ve Sağlık Araştırması. Ankara, Türkiye; 2019.

8. Hubbard S, Cooper N, Kendrick D, Young B, Wynn PM, He Z, et al. Network meta-analysis to evaluate the effectiveness of interventions to prevent falls in children under age 5 years. Inj Prev 2015;21(2):98-108.

9. Kendrick D, Ablewhite J, Achana F, et al. Keeping Children Safe: a multicentre programme of research to increase the evidence base for preventing unintentional injuries in the home in the underfives. Southampton (UK): NIHR Journals Library; 2017 Jul.

10. Achana FA, Sutton AJ, Kendrick D, Wynn P, Young B, Jones DR, et al. The effectiveness of different interventions to promote poison prevention behaviours in households with children: a network meta-analysis. PLoS One 2015;10(4):e0121122. 
11. Bhatta S, Mytton J, Deave T. Environmental change interventions to prevent unintentional home injuries among children in low-and middle-income countries: A systematic review and meta-analysis. Child Care Health Dev 2020;46(5):537-51.

12. Uğur Baysal S. Yaralanmaların ve Zehirlenmelerin Onlenmesi. Guvenlik Kontrol Listesi(Supp). Turkiye Klinikleri J Pediatr Sc 2015;11(4):90-5.

13. Walz, M. C. Evaluation of Child Safety Seat Registration (No. HS-809 518) 2002.

14. T.C. Sağlık Bakanlığı. (2014). Sağ lık İstatistikleri Yıllığı 2013.

15. Andijani S. Knowledge, attitude, and practice of parents regarding children's car safety seat. International Journal of Medicine in Developing Countries 2017;1(2),46-51.

16. Task Force on Sudden Infant Death Syndrome. SIDS and other sleeprelated infant deaths: updated 2016 recommendations for a safe infant sleeping environment. Pediatrics 2016;138(5):e20162940.

17. Gilbert R, Salanti G, Harden M, See S. Infant sleeping position and the sudden infant death syndrome: systematic review of observational studies and historical review of recommendations from 1940 to 2002. Int J Epidemiol 2005;34(4):874-87.

18. Gilbert R. The changing epidemiology of SIDS. Arch Dis Child 1994;70(5):445-9.
19. Safe Sleep and Your Baby: How Parents Can Reduce the Risk of SIDS and Suffocation. Available at: https://patiented.solutions.aap.org/ handout.aspx?gbosid=156543. Last available time: 1 September 2021.

20. Orsagh-Yentis D, McAdams RJ, Roberts KJ, McKenzie LB. ForeignBody Ingestions of Young Children Treated in US Emergency Departments:1995-2015. Pediatrics 2019;143(5):e20181988.

21. New AAP study finds that foreign-body ingestions by small children rose $91 \%$. Available at https://kidsindanger.org/2019/04/newaap-study-finds-that-foreign-body-ingestions-by-small-childrenrose-91/.Last available time: 1 September 2021.

22. U.S. Consumer Product Safety Commission. CPSC Warns Consumers of Suffocation Danger Associated with Children's Balloons. Available at: https://www.cpsc.gov/s3fs-public/5087. pdf. Last available time: 18 September 2021.

23. Yılmaz Kurt F, Aytekin A. 0-6 Yaş Grubu Çocuklarda Ev Kazaları. HSP 2015;2(1):22-32.

24. Kondolot M, Akyıldız B, Görözen F, Kutoğlu S, Patıroğlu T. Çocuk Acil Servisine Getirilen Zehirlenme Olgularının Değerlendirilmesi. Çocuk Sağlığı ve Hastalıkları Dergisi 2009;52:68-74.

25. Güloğlu R, et al. Falling television related child injuries in Turkey: 10-year experience. Turkish Journal of Trauma \& Emergency Surgery 2012;18(1):61-4. 